\title{
Aplikasi Pupuk Kandang Pada Tanah Merah (Ultisol Soil) Di Lahan Pertanian Batam, Kepulauan Riau
}

\author{
Mia Juliana Siregar ${ }^{1 *}$, Adi Nugroho ${ }^{2}$ \\ ${ }^{1,2}$ Industrial Engineering Study Program, Faculty of Engineering, Universitas Universal, Batam \\ *Koresponden email: mia_juliana.1988@yahoo.com
}

Diterima: 9 Februari 2021

Disetujui: 23 Maret 2021

\begin{abstract}
Ultisol soil is a less fertile soil characterized by low soil fertility rate, high acidity with $\mathrm{pH}<5$, high $\mathrm{Al}$ saturation. This land has an area of $25 \%$ of the total land area of Indonesia. Riau Island is one of the provinces dominated by Ultisol land, so many land is not productive to use as agricultural land. This research was conducted to look at the characteristics of red soil in the agricultural land in Batam City after mixed with organic material in this case which is used is goat manure and chicken manure. From the results of research, the addition of goat manure and chicken manure that is incubated for 30 days can already give changes to the physical and chemical character of the soil, such as soil becoming more loose, having higher water content, increasing soil $\mathrm{C}$ organic, Nitorgen, $\mathrm{P}_{2} \mathrm{O}_{5}, \mathrm{~K}, \mathrm{Mg}$, and $\mathrm{Mn}$, able to reduce $\mathrm{Fe}$ levels in the soil. The addition of chicken manure can increase the available of Phosphate, gives $\mathrm{K}, \mathrm{Mg}$, and Mn higher than compared mixing blanko with goat manure. The addition of goat manure can increase the total of $\mathrm{C}$ organic and $\mathrm{N}$ in the soil is higher than chicken manure.
\end{abstract}

Keywords: Ultisol, organic, manure, goat, chicken

\begin{abstract}
Abstrak
Tanah Ultisol merupakan tanah yang kurang produktif yang ditandai dengan rendahnya tingkat kesuburan, keasaman yang tinggi dengan $\mathrm{pH}<5$, kejenuhan $\mathrm{Al}$ yang tinggi memiliki total $25 \%$ dari luas daratan Indonesia. Kepulauan Riau merupakan salah satu Provinsi yang didominasi oleh tanah Ultisol, sehingga banyak lahan yang tidak produktif untuk digunakan sebagai lahan pertanian. Tujuan penelitian adalah mengetahui karakteristik tanah merah di lahan pertanian di Kota Batam setelah dicampurkan dengan bahan organik dalam hal ini yang digunakan adalah kotoran kambing dan kotoran ayam. Dari hasil penelitian penambahan kotoran kambing dan kotoran ayam lalu diinkubasi selama 30 hari sudah dapat memberikan perubahan terhadap karakter kimia tanah, seperti lebih gembur, memiliki kadar air lebih tinggi, meningkatkan kandungan $\mathrm{C}$ organik tanah, kandungan Nitrogen, $\mathrm{P}_{2} \mathrm{O}_{5}, \mathrm{~K}, \mathrm{Mg}$, dan $\mathrm{Mn}$ tanah, serta mampu menurunkan kadar Fe dalam tanah. Penambahan kotoran ayam dapat meningkatkan Fosfat tersedia, $\mathrm{K}, \mathrm{Mg}$, dan $\mathrm{Mn}$ lebih tinggi dibandingkan dengan mencampurkan blanko dengan kotoran kambing. Penambahan kotoran kambing dapat meningkatkan total $\mathrm{C}$ organik, $\mathrm{N}$ tanah lebih tinggi dibandingkan kotoran ayam.
\end{abstract}

Kata Kunci: Ultisol, organik, kotoran, kambing, ayam

\section{Pendahuluan}

Tanah merupakan sumber fundamental dalam memenuhi kebutuhan dasar manusia, seperti makanan, serta menjadi tempat manusia berlindung [1]. Tanah merupakan sebuah bentuk kehidupan yang di dalamnya hidup berbagai proses vital bagi kehidupan yang dihuni oleh fungi, alga, bakteri, fauna dan akar tanaman [2]. Formasi tanah berbeda dari satu bagian dunia dengan bagian lainnya, bahkan dari satu wilayah dengan wilayah lainnya. Perbedaan ini tergantung pada dimana dan material penyusunnya. Setidaknya ada lima faktor utama yang mempengaruhi berbagai jenis tanah, diantaranya, iklim, organisme yang hidup di dalam tanah, relief landscape, bahan induk, dan umur tanah serta beberapa komponen benar-benar diubah berubah [3].

Sekitar 5,5 juta penduduk dunia di negara berkembang [4], sebagian besar penduduknya bergantung pada kegiatan pertanian. Tetapi faktanya, sekitar 1 juta penduduk merupakan pemilik lahan yang berukuran $<2$ ha [5]. Bagi aktivitas pertanian karakter tanah dan unsur hara tanah merupakan bagian yang sangat penting untuk diketahui. Beberapa pulau di Indonesia, seperti Sumatera, Kalimantan, Sulawesi dan Papua serta sebagian kecil di Pulau Jawa didominasi oleh tanah Ultisol [6] dengan karakteristik $\mathrm{pH}$ tanah yang rendah, kadar bahan organik yang minim, dan kapasitas tukar kation (KTK) 
yang rendah [7], konsentrasi toksik dari $\mathrm{Al}, \mathrm{Fe}, \mathrm{Mn}$ yang tinggi, kekurangan unsur $\mathrm{Ca}, \mathrm{Mg}$, dan $\mathrm{K}$ [6]. Dengan sumber daya yang terbatas, manajemen kualitas tanah menjadi hal yang sangat penting untuk diperkuat dan dipertahankan kelanjutan ekosistemnya. Penurunan kualitas tanah pada abad 21 telah menjadi masalah global yang sangat parah di daerah tropis dan subtropis [8].

Di wilayah Sumatera, sebaran tanah Ultisol paling luas ditemukan di Provinsi Riau dan selanjutnya provinsi Sumatera Utara dengan luas mencapai 1.524.414 ha [7]. Tanah ini mempunyai potensi yang besar mengingat ukurannya yang cukup luas. Kota Batam yang merupakan pusat kota di Kepulauan Riau didominasi oleh tanah merah ini (tanah cenderung berwarna merah hingga merah-kuning). Berdasarkan data BPS kota Batam [9], per tahun 2016 memiliki lahan yang produktif untuk kegiatan pertanian seluas $4.880 \mathrm{Ha}$ dengan hasil panen sebesar 30.983 ton yang terdiri dari cabe, ketimun, terong, kacang panjang, bayam, kangkung, sawi, pare, cabe rawit, pitula dan buncis. Jika dilihat, tidak semua jenis sayuran yang bisa dibudidayakan di daerah dataran rendah dapat dibudidayakan di Kota Batam. Tanah yang bersifat masam dengan $\mathrm{pH}<6,5$, biasanya lebih berwarna merah hingga ke kuning karena kandungan $\mathrm{Al}$, $\mathrm{Fe}$, dan Mn yang tinggi.

Tanah Ultisol (tanah merah) merupakan tanah yang kurang subur yang ditandai dengan rendahnya tingkat kesuburan tanah, keasaman yang tinggi dengan $\mathrm{pH}<5$ kemungkinan disebabkan oleh eksploitasi berlebihan dan erosi, kurangnya kandungan kimia tanah yang dibutuhkan tanaman [10]. Tanah merah memiliki kapasitas tukar kation (KTK), kejenuhan basa (KB), kandungan Alumunium (kejenuhan $\mathrm{Al}$ ) tinggi, kandungan C-organik yang rendah, fiksasi Pospor (P) tinggi, kandungan Fe dan Mn mendekati batas kriteria meracuni tanaman dan sangat sensitif terhadap erosi [7]. Ion $\mathrm{Al}$ telah terbukti sangat beracun untuk tanaman, menyebabkan penghambatan perpanjangan akar dengan menghancurkan struktur sel dari puncak akar dan sehingga mempengaruhi asupan air dan nutrisi oleh akar. Sebagai konsekuensinya, pertumbuhan dan perkembangan tanaman secara serius terhambat. Di sisi lain, fosfor (P) mudah diperbaiki oleh mineral tanah liat yang kaya akan asam tanah, termasuk berbagai besi oksida dan kaolinite, dan karenanya render tidak tersedia untuk penyerapan akar. Keracunan Al dan kekurangan $\mathrm{P}$ dianggap dua kendala utama untuk produksi tanaman di tanah asam [11].

Karakter Ultisol dapat diperbaiki dengan pemberian bahan organik atau tindakan pemupukan. Sehingga tanah dapat dimanfaatkan untuk proses budidaya tanaman atau kegiatan pertanian. Selain pemupukan tindakan pengapuran juga dapat menjadi alternatif tindakan untuk membuat tanah Ultisol menjadi produktif [12]. Hasil penelitian [13] menunjukkan bahwa pemupukan dapat mengurangi toksisitas $\mathrm{Al}$ dan meningkatkan unsur hara yang diperlukan untuk tanaman dapat tumbuh di tanah asam. Toksisitas aluminium dan infertilitas terjadi secara simultan dalam tanah asam. Aplikasi limbah logam berat dikombinasikan dengan bahan organik dapat menurunkan keasaman dan meningkatkan kesuburan tanah. Limbah logam berat (Alkaline slag) merupakan hasil akhir dari pengolahan industri baja yang memiliki $\mathrm{pH}>11,5$ [14].

Penelitian lainnya menggunakan zeolite dan kapur [15], abu terbang [16], pupuk kandang, kapur dan pupuk kimia seperti urea, SP-36 dan $\mathrm{KCl}$ [17] dapat memperbaiki sifat kimia tanah Ultisol. Kajian mikrobiologis Ultisol menunjukkan bahwa populasi mikroba cukup rendah, berkisar 29,4.101 hingga $14,8.104 \mathrm{cfu} / \mathrm{gram}$ [18]. Pada lahan subur mengandung > 100 juta mikroba per gram tanah. Mikroba pelarut fosfat dapat dimanfaatkan karena kemampuannya dalam melarutkan $\mathrm{P}$ terikat tanah dan pupuk menjadi P-tersedia [19]. Penelitian ini dilakukan untuk melihat karakteristik tanah merah dilahan pertanian di Kota Batam setelah dicampurkan dengan bahan organik dalam hal ini yang digunakan adalah pupuk kambing dan pupuk ayam. Harapannya adalah tanah yang masam dan ber-pH rendah ini akan mengalami perubahan karakteristik fisik dan kimia akibat pemberian pupuk kandang.

\section{Metode Penelitian \\ Lokasi Penelitian}

Penelitian ini mengambil sampel tanah Ultisol dari lahan pertanian di wilayah Kelurahan Rempang Cate, Batam. Kondisi struktur tanah yang menjadi salah satu sentral pertanian di Kota Batam dapat dilihat pada Gambar 1 dan Gambar 2. 


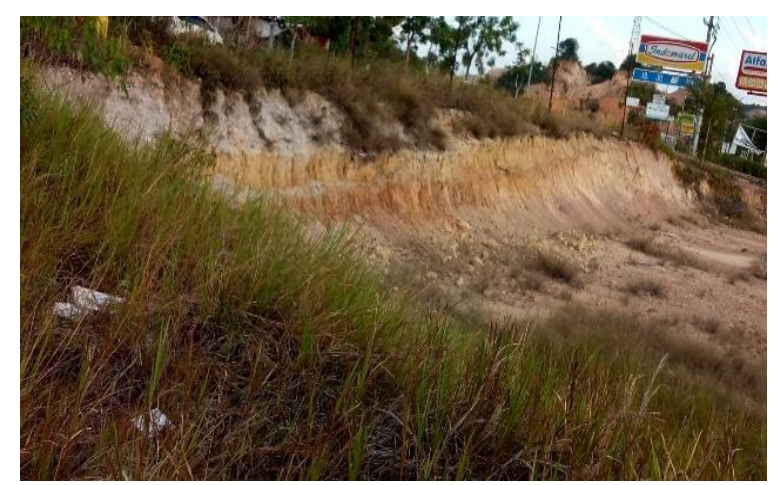

Gambar 1. Penampakan lahan pertanian Sumber: [20].

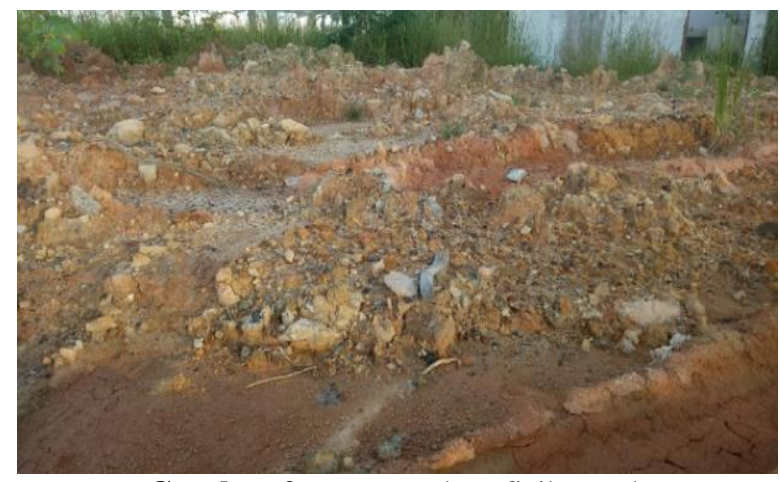

Gambar 2. Penampakan fisik tanah Sumber: [20].

\section{Metode Penelitian}

Penelitian ini menggunakan variabel bebas yaitu level pemberian pupuk kandang. Kedua faktor ini diharapkan memberikan pengaruh pada perubahan karakteristik tanah merah. Penelitian juga menggunakan blanko tanah merah tanpa tambahan pemberian pupuk di dalamnya. Kedua bahan ini dicampurkan (kotoran hewan dan tanah Ultisol) dengan perbandingan $(\mathrm{Kg}) 1: 1 ; 1: 2$ (bk/bk) dan diinkubasi selama 30 hari. Kemudian campuran tanah dan pupuk kandang yang telah diinkubasi digunakan sebagai media tanam pada tanaman sayuran contoh.

\section{Prosedur Kerja}

Tanah Ultisol yang digunakan pada penelitian ini diambil secara acak dari lahan pertanian di wilayah kelurahan Rempang Cate, Batam. Kemudian tanah tersebut dikering-anginkan terlebih dahulu, lalu digerus dan disaring hingga halus. Tanah yang digunakan pada penelitian ini memiliki karakter seperti yang terlihat pada Tabel 1.

Tabel 1. Karakteristik tanah merah.

\begin{tabular}{cc}
\hline Parameter & Nilai \\
\hline $\mathrm{pH}$ & 4,85 \\
$\mathrm{C}$ Organik $(\%)$ & 1,74 \\
$\mathrm{~N}(\%)$ & 0,07 \\
$\mathrm{P}_{2} \mathrm{O}_{5}(\mathrm{ppm})$ & 11,6 \\
$\mathrm{~K}(\mathrm{me} / 100 \mathrm{~g})$ & 0,38 \\
$\mathrm{Ca}(\mathrm{me} / 100 \mathrm{~g})$ & 0,36 \\
$\mathrm{Mg}(\mathrm{me} / 100 \mathrm{~g})$ & 0,30 \\
$\mathrm{Al}-\mathrm{dd}(\mathrm{me} / 100 \mathrm{~g})$ & 0,22 \\
$\mathrm{H}-\mathrm{dd}(\mathrm{me} / 100 \mathrm{~g})$ & 0,06 \\
\hline
\end{tabular}

Sumber: [21] 

Tabel 2.

Berdasarkan hasil uji fisik dan analisis kimia, tanah ini memiliki karakter seperti yang terlihat pada

Tabel 2. Karakteristik Ultisol

\begin{tabular}{llll}
\hline Parameter & Sumut & Lampung & Kal. Sel \\
\hline $\mathrm{pH}$ & 6,52 & 5,2 & 4,7 \\
Bahan-Organik & & & \\
$\mathrm{C}(\%)$ & 0,97 & 1,60 & 1,46 \\
$\mathrm{~N}(\%)$ & 0,013 & 0,16 & 0,11 \\
$\mathrm{C} / \mathrm{N}$ & & 10 & 14 \\
$\mathrm{P}_{2} \mathrm{O}_{5}$ & 20,9 & 40 & 19 \\
$(\mathrm{mg} / 100 \mathrm{~g})$ & & & \\
$\mathrm{K} 2 \mathrm{O}$ mg/100g) & & 7 & 5 \\
$\mathrm{Nilai}$ tukar kation & & \\
$\mathrm{Ca}(\mathrm{m} . \mathrm{e} / 100 \mathrm{~g})$ & & 2,23 & 0,99 \\
$\mathrm{Mg}$ & & 0,52 & 0,15 \\
(m.e/100g) & & & \\
$\mathrm{K}(\mathrm{m} . \mathrm{e} / 100 \mathrm{~g})$ & & 0,10 & 0,05 \\
$\mathrm{KTK}$ & & 8,91 & 5,11 \\
(m.e/100g) & & & \\
Unsur mikro & & & \\
Fe (ppm) & & 0,97 & 421,11 \\
$\mathrm{Mn}(\mathrm{ppm})$ & & 1,13 & 13,26 \\
Fe bebas (\%) & & 0,37 & 0,60 \\
Potasium (\%) & 0,491 & & \\
Fosfor (\%) & 20,9 & & \\
\hline & Sumber: [22] &
\end{tabular}

\section{Hasil dan Pembahasan}

Penelitian ini difokuskan untuk menganalisa karakteristik tanah merah secara fisik dan kimia. Tanah yang dianalisa diambil secara acak dari lahan yang digunakan untuk bercocok tanam di wilayah Barelang yang banyak dimanfaatkan warga sebagai lahan bertani.

\section{Karakteristik Fisik Tanah Setelah Dicampur Kotoran Hewan}

Tanah Ultisol sangat peka terhadap erosi [23] karena mempunyai pori aerasi dan indeks stabilitas yang rendah sehingga tanahnya sangat mudah memadat. Tekstur tanah yang liat juga menyebabkan tanah memiliki konsentrasi yang lebih lekat [24]. Karakter tanah yang mudah memadat ini menghambat pertumbuhan akar tanaman karena daya tembus nya berkurang. Proses pencampuran antara tanah dan kotoran kambing dan ayam membuat tanah merah yang bersifat liat menjadi lebih poros atau berongga seperti yang terlihat pada Gambar 4, Gambar 5, Gambar 6. Kondisi tanah yang berongga dapat memperbaiki struktur tanah dalam proses pengikatan oksigen sehingga membantu tanaman untuk dapat hidup lebih baik.

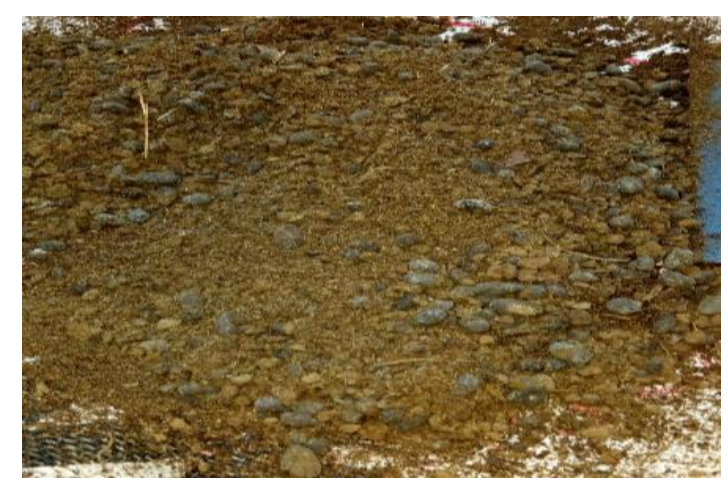

Gambar 4. Tanah merah dan kotoran kambing Sumber: [20]. 


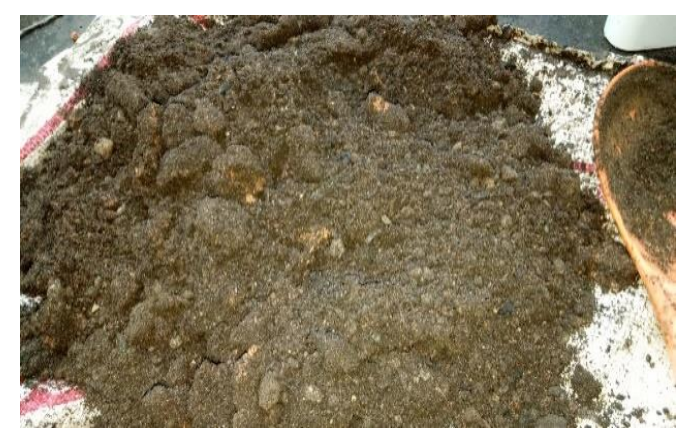

Gambar 5. Tanah merah dan kotoran ayam Sumber: [20].

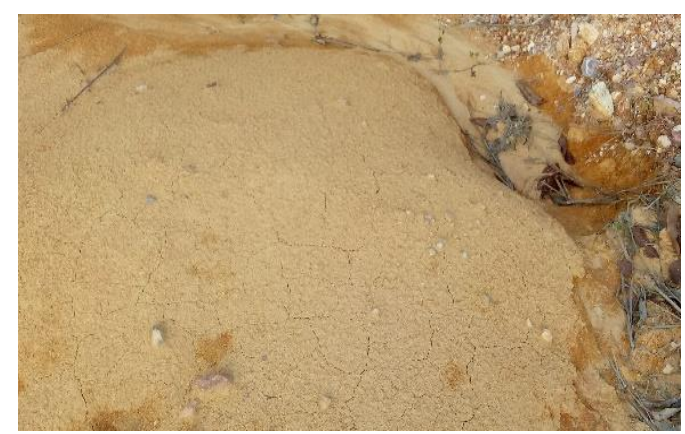

Gambar 6. Gambar tanah merah sebagai blanko Sumber: [20].

Pemberian pupuk pada tanah Ultisol dapat meningkatkan pori tanah sehingga terlihat lebih gembur dan menurunkan kepadatan tanah. Pemberian bahan dengan kandungan organik yang tinggi akan menurunkan berat volume tanah yang membuat tanah menjadi gembur dan longgar, sehingga meningkatkan kadar air tanah dan kapasitas air tersedia [25].

\section{Karakteristik Kimia Tanah Setelah Dicampur Kotoran Hewan}

Beberapa kendala tanah Ultisol yaitu tingkat keasaman tinggi ditunjukkan dengan nilai $\mathrm{pH}$ rata-rata $<$ 4,50, kejenuhan Al tinggi, miskinnya kandungan hara makro terutama $\mathrm{P}, \mathrm{K}, \mathrm{Ca}$, dan $\mathrm{Mg}$, dan kandungan bahan organik rendah [26]. Keasaman berhubungan dengan kandungan Al yang tinggi, hal ini disebabkan oleh Ultisol yang berasal dari pelapukan mineral mudah lapuk. Sehingga Ultisol didominasi oleh Al [27]. Karakter tanah yang telah diinkubasi selama 30 hari dapat dilihat pada Tabel 4.

Tabel 4. Karakteristik kimia tanah (1)

\begin{tabular}{lcc}
\hline Parameter & $1 \mathrm{~B}: 2 \mathrm{~A}$ & $1 \mathrm{~B}: 2 \mathrm{~K}$ \\
\hline $\mathrm{pH}$ & 6 & 6 \\
Total C-Organik $(\%)$ & 3,56 & 6,65 \\
$\mathrm{~N}(\%)$ & 1,04 & 1,77 \\
$\mathrm{P}_{2} \mathrm{O}_{5}(\mathrm{mg} / \mathrm{kg})$ & 6353,22 & 1425,77 \\
$\mathrm{Fe}(\%)$ & 1,02 & 0,02 \\
$\mathrm{~K}(\%)$ & 1,15 & 0,26 \\
$\mathrm{Mg}(\%)$ & 0,95 & 0,17 \\
$\mathrm{Mn}(\mathrm{mg} / \mathrm{kg})$ & 446,05 & 29,54 \\
Kadar air $(\%)$ & 25,22 & 10,86 \\
\hline \multicolumn{3}{c}{}
\end{tabular}

Karakter kedua bahan organik diatas menghasilkan perbedaan yang cukup signifikan. Penambahan kotoran ayam dengan proporsi 2 kali lipat blanko (1B:2A dan 1B:2K). Kompos membantu meningkatkan kadar air. Dari hasil pengujian pada Tabel 4 diatas, menunjukkan kadar air lebih tinggi jika blanko atau tanah merah dicampurkan dengan pupuk ayam, yaitu senilai 25,22\%. [25] menyatakan pemberian bahan organik dapat memberikan kadar air tersedia dalam tanah dan menurunkan volume berat tanah, porositas. pH tanah juga mengalami kenaikan akibat pemberian pupuk kandang. Kenaikan pH dikarenakan bahan organik yang bersifat amfoter (dapat bersifat asam atau basa tergantung medianya) [28]. 
Peningkatan C-organik dan N-total juga terjadi pada tanah merah yang digunakan pada penelitian ini. Penambahan kotoran ayam, membuat Fosfat tersedia, $\mathrm{K}, \mathrm{Mg}$, dan $\mathrm{Mn}$ lebih tinggi dibandingkan dengan mencampurkan blanko dengan kotoran kambing. Akan tetapi penambahan kotoran kambing dapat meningkatkan total $\mathrm{C}$ organik, $\mathrm{N}$ tanah lebih tinggi dibandingkan kotoran ayam. Bahan organik mampu menyumbang peningkatan C-organik dan N-total tanah [28]. Peningkatan ini merupakan hasil dekomposisi lanjut dari pupuk kandang akibatnya P-tersedia juga mengalami peningkatan akibat bahan organik yang meningkatkan ketersediaan fosfor dalam tanah [29]. Penambahan bahan organik dengan proporsi lebih kecil dibandingkan blanko dapat dilihat pada Tabel 5 dengan pelabelan (2B:1A dan $2 \mathrm{~B}: 1 \mathrm{~K})$.

Tabel 5. Karakteristik kimia tanah (2)

\begin{tabular}{ccc}
\hline Parameter & $2 \mathrm{~B}: 1 \mathrm{~A}$ & $2 \mathrm{~B}: 1 \mathrm{~K}$ \\
\hline $\mathrm{pH}$ & 5 & 5 \\
Total C-Organik $(\%)$ & 4,03 & 11,99 \\
$\mathrm{~N}(\%)$ & 1,34 & 3,17 \\
$\mathrm{P}_{2} \mathrm{O}_{5}(\mathrm{mg} / \mathrm{kg})$ & 4973,48 & 1848,49 \\
$\mathrm{Fe}(\%)$ & 0,02 & 0,64 \\
$\mathrm{~K}(\%)$ & 0,64 & 0,49 \\
$\mathrm{Mg}(\%)$ & 0,52 & 0,25 \\
$\mathrm{Mn}(\mathrm{mg} / \mathrm{kg})$ & 69,62 & 101,40 \\
Kadar air $(\%)$ & 26,32 & 20,24 \\
\hline
\end{tabular}

Sumber: [20].

Penambahan jumlah blanko 2 kali lipat dibandingkan bahan organik (pupuk kandang) ternyata juga dapat memperbaiki struktur kimia tanah. Perubahan yang terjadi pada struktur kimia tanah pada sampel uji ini tidak lebih besar atau tidak sesignifikan jika blanko diberikan tambahan pupuk dengan proporsi lebih besar dibandingkan dengan blanko. Akan tetapi sudah dapat memperbaiki struktur kimia tanah menjadi lebih baik kandungan haranya. Jika dibandingkan dengan kandungan hara blanko tanpa penambahan bahan organik, terlihat perbedaan nyata terhadap perubahan unsur hara tanah seperti pada Tabel 6.

Tabel 6. Perbandingan blanko, blanko+k.ayam, dan blanko+k.kambing

\begin{tabular}{lccc}
\hline Parameter & Blanko & Blanko+K.Ayam & Blanko+K.Kambing \\
\hline $\mathrm{pH}$ & 4,85 & 6 & 6 \\
Total C-Organik $(\%)$ & 1,74 & 3,56 & 6,65 \\
$\mathrm{~N}(\%)$ & 0,07 & 1,04 & 1,77 \\
$\mathrm{P}_{2} \mathrm{O}_{5}(\mathrm{mg} / \mathrm{kg})$ & 11,6 & 6353,22 & 1425,77 \\
$\mathrm{Fe}(\%)$ & 0,42 & 1,02 & 0,02 \\
$\mathrm{~K}(\%)$ & 0,30 & 1,15 & 0,26 \\
$\mathrm{Mg}(\%)$ & 0,30 & 0,95 & 0,17 \\
$\mathrm{Mn}(\mathrm{mg} / \mathrm{kg})$ & 13,26 & 446,05 & 29,54 \\
\hline
\end{tabular}

Perubahan yang terjadi pada karakter tanah merah (blanko) dengan memberikan campuran pupuk kandang, seperti kotoran ayam dan kotoran kambing. sudah cukup mampu meningkatkan kandungan $\mathrm{C}$ organik tanah, kandungan Nitrogen, $\mathrm{P}_{2} \mathrm{O}_{5}, \mathrm{~K}, \mathrm{Mg}$, dan $\mathrm{Mn}$ tanah, serta mampu menurunkan kadar $\mathrm{Fe}$ dalam tanah. Dengan perbaikan komposisi tanah maka bahan organik nyata dapat meningkatkan kesuburan tanah, meningkatkan pertumbuhan tanaman, dan hasil tanaman, sehingga akan meningkatkan lahan produktif untuk kegiatan pertanian. Kotoran hewan memiliki komposisi hara yang berbeda tergantung pada jumlah dan jenis makanannya. Kandungan hara bahan organik ternak dapat dilihat pada Tabel 7.

Secara umum, kandungan hara pada pupuk organik jauh lebih menguntungkan dibanding penggunaan pupuk anorganik atau pupuk kimia. Pupuk organik dapat mempertahankan kualitas tanah, memperbaiki sifat kimia tanah dengan penambahan unsur-unsur mikro ke dalam tanah. Sementara penggunaan pupuk anorganik dapat menurunkan fisik, kimia, dan biologi tanah [32]. 
Tabel 7. Kandungan hara pupuk kandang

\begin{tabular}{ccc}
\hline Parameter & Kotoran Ayam $^{1)}$ & Kotoran Kambing $^{2)}$ \\
\hline $\mathrm{pH}$ & 7,61 & 7,08 \\
C-Organik (\%) & 15,18 & 22,78 \\
N-Total (\%) & 1,65 & 1,14 \\
$\mathrm{P}(\%)$ & 0,06 & 0,264 \\
$\mathrm{~K}(\%)$ & 7,94 & 0,423 \\
Rasio C/N & 9,2 & 19,9 \\
\hline & Sumber: $^{1)}[30] ;^{2)}[31]$
\end{tabular}

\section{Kesimpulan}

Penambahan pupuk kandang dalam hal ini kotoran kambing dan kotoran ayam yang diinkubasi selama 30 hari sudah dapat memberikan perubahan terhadap karakter fisik dan kimia tanah, seperti tanah menjadi lebih gembur, memiliki kadar air lebih tinggi, meningkatkan kandungan $\mathrm{C}$ organik tanah, kandungan Nitrogen, $\mathrm{P}_{2} \mathrm{O}_{5}, \mathrm{~K}, \mathrm{Mg}$, dan $\mathrm{Mn}$ tanah, serta mampu menurunkan kadar Fe dalam tanah.

Penambahan kotoran ayam dan kotoran kambing dengan proporsi 2 kali lipat dari blanko (tanah merah) (1B:2A dan 1B:2K) dapat meningkatkan kandungan $\mathrm{C}$ organik tanah, kandungan Nitorgen, $\mathrm{P}_{2} \mathrm{O}_{5}$, $\mathrm{K}, \mathrm{Mg}$, dan $\mathrm{Mn}$ tanah lebih besar dibandingkan jika proporsi blanko menjadi 2 kali lipat dari kotoran ayam dan kotoran kambing. Penambahan kotoran ayam, Fosfat tersedia, K, Mg, dan Mn lebih tinggi dibandingkan dengan mencampurkan blanko dengan kotoran kambing. Penambahan kotoran kambing dapat meningkatkan total $\mathrm{C}$ organik, $\mathrm{N}$ tanah lebih tinggi dibandingkan kotoran ayam.

\section{Ucapan Terima Kasih}

Penulis ingin mengucapkan terima kasih kepada Kementerian Riset dan Teknologi Perguruan Tinggi yang telah memberikan bantuan hibah skema Penelitian Dosen Pemula (PDP) kepada kami untuk melakukan penelitian ini. Terima kasih juga penulis sampaikan kepada seluruh pihak yang telah membantu penulis dalam menyelesaikan penelitian ini dan proses penulisannya sampai selesai.

\section{Referensi}

[1] S. Bashir, Javed, I. Bibi and N. Ahmad, "Soil and Water Conservation," Pakistan, University of Agriculture, Faisalabad, 2017, pp. 263-286.

[2] G. Subowo, "Pemberdayaan Sumberdaya Hayati Tanah untuk Rehabilitasi Tanah Ultisol Terdegradasi," Jurnal Sumberdaya Lahan, pp. 79-89, 2012.

[3] Soil Science Society of America, "Soils Overview," Soil Science Society of America, 2019. [Online]. Available: http://www.soils.org. [Accessed February 2020].

[4] L. Van Pham and C. Smith, "Drivers of Agricultural Sustainability in Developing Countries," A review. Environ. Syst. Decis, vol. 34, p. 34: 326-341, 2014.

[5] IFAD, " The Rural Poverty Report 2011," International Fund for Agricultural Development, Rome, Italy, 2010.

[6] E. Susilo, Parwito and H. Pujiwati, "Perbaikan Pertumbuhan dan hasil Kacang Tanah di Tanah Ultisol dengan Aplikasi Pupuk P dan K," Agritepa, pp. 126-137, 2019.

[7] A. Mulyani, A. Rachman. and A. Dairah, "Penyebaran Lahan Masam, Potensi dan Ketersediaannya Untuk Pengembangan Pertanian," in Prosiding Simposium Nasional Pendayagunaan Tanah Masam, Bogor :, 2010.

[8] R. Lal, "Restoring Soil Quality to Mitigate Soil Degradation," Journal Sustainability, vol. 7, pp. 7 (5) : 5875-5895, 2015.

[9] Dinas Kelautan, Perikanan, Pertanian dan Kehutanan Kota Batam, "Luas dan Produksi Panen Tanaman Sayur-Sayuran Kota Batam menurut Jenis Tanaman, 2013-2016," Badan Pusat Statistik, Kota Batam : , 2016.

[10] M. Anikwe, J. Eze and A. Ibudialo, "Influence of Lime and gypsum application on soil properties and yiel of cassava (Manihot esculenta Crantz) in degrede Ultisol in Agbani Enugu Southeastern Nigeria," J. Soil and Tiilage Research, vol. 158, pp. 158: 32-38, 2016.

[11] S. J. Zheng, "Crop Production on Acidic Soils: Overcoming Aluminium Toxicity and Phosphorus Deficiency," Annals of Botany, vol. 106, p. 106 (1) 183-184, 2010. 
[12] D. L. Hakim, "Tanah Ultisol," in Ensiklopedi Tanah Di Indonesia, Ponorogo, Uwais Inspirasi Indonesia, 2019, pp. 56-61.

[13] W.-r. Zhao, J.-y. Li, J. Jiang, H.-1. Lu, Z.-n. Hong, W. Qian, R.-k. Xu, K.-Y. Deng and P. Guan, "The Mechanisms Underlying the Reduction in Aluminum Toxicity and Improvements in the Yield of Sweet Potato (Ipomoea Batatas L.) After Organic and Inorganic Amendment of an Acidic Ultisol," $J$. Agriculture, Ecosystems and Environment, vol. 288 (2020), pp. 288 : 1-10, 2020.

[14] H. I. Gomes, M. M. William, H. A. Baxter, A. P. Jarvis, I. T. Burke, D. I. Stewar and M. Rogerson, "Option for Managing Alkaline Slag Leachate: A life Cycle Assessment," Journal of Cleaner Production, vol. 202, pp. 202 : 401-412, 2018.

[15] E. P. Handayani, "Optimization of Production of Sweet Corn (Zea Mays Saccharata L.) in the Ultisol Soil with The Application of Zeolite and Manure," in Seminar Nasional Sains \& Teknologi VI Lembaga Penelitian dan Pengabdian Universitas Lampung, Lampung :, 2015.

[16] A. Hermawan, Sabaruddin, Marsi, R. Hayati and Warsito., "Perubahan Jerapan P pada Ultisol Akibat Pemberian Campuran Abu Terbang Batubara-Kotoran Ayam," Jurnal Ilmu Tanah dan Agroklimatologi, vol. 11 (1), pp. 11 (1) : 1-10, 2014.

[17] Ermadani and A. Muzar, "Pengaruh Aplikasi Limbah Cair Pabrik Kelapa Sawit terhadap Hasil Kedelai dan Perubahan Sifat Kimia Tanah Ultisol," Jurnal Agron. Indonesia, vol. 39 (3) , pp. 39 (3) : 160-167, 2011.

[18] Prihastuti, "Upaya Pengelolaan Biologis Lahan Kering Masam Ultisol," J. El-Hayah, vol. 2(2), pp. 2 (2) 104-111, 2012.

[19] Khamdanah, T. R. Amanda and J. Purwani, "Efektivitas Bakteri Pelarut Fosfat Asal Tanah Ultisol Lebak Banten Terhadap Pertumbuhan Kedelai (Glycine max L.)," in Prosiding Seminar Nasional Pertanian Organik, Bogor, 2014.

[20] M. Siregar, Dokumentasi Sendiri, Batam, 2020.

[21] Prihastuti and Purwantoro, "Kajian Penggunaan Pupuk Hayati Kemasan untuk Tanaman Kacang Tanah di Lahan Kering Masam, Lampung," Jurnal Sains dan Matematika, pp. Vol3 No1, 7-13, 2014.

[22] Sumono, S. Parinduri, N. Huda and N. Ichwan, "The Utilization of Ultisol Soil for Horticulture Crops Cultivation," in IOP Conference Series : Earth and Environmental Science, 2018.

[23] S. Handayani and Karnilawati, "Karakterisasi dan Klasifikasi Tanah Ultisol di Kecamatan Indrajaya Kabupaten Pidie," Jurnal Ilmiah Pertanian, pp. Vol 14 No 2. 52-60, 2018.

[24] B. Andalusia, Zainabun and T. Arabia, "Karakteristik Tanah Ordo Ultisol di Perkebunan Kelapa Sawit PT. Perkebunan Nusantara I (Persero) Cot Girek Kabupaten Aceh Utara," Jurnal Kawisata, pp. 45-49, 2016.

[25] Y. I. Intara, A. Sapei, Erizal, S. N. and M. H. B. Djoefrie, "Pengaruh Pemberian Bahan Organik Pada Tanah Liat dan Lempung Berliat Terhadap Kemampuan Mengikat Air," Jurnal Ilmu Pertanian Indonesia, pp. 130-135, 2011.

[26] A. Kusumastuti, "Soil Available P Dynamics, pH, Organic-C, and P Uptake of Patchouli (Pogostemon Cablin Benth.) at Various Dosages of Organic Matters and Phosphate in Ultisols.," Jurnal Penelitian Pertanian, pp. 145-151, 2014.

[27] K. H. Tan, Principles of Soil Chemistry Fourth Edition, New York: CRC Press Tailor and Francis , 2010.

[28] A. Alibasyah, "Perubahan Beberapa Sifat FIsika dan Kimia Ultisol Akibat Pemberian Pupuk Kompos dan Kapur Dolomit pada Lahan Berteras," Jurnal Floratek, vol. 11 (1), pp. 11 (1) : 75-87, 2016.

[29] M. N. Sari, Sudaarsono and Darmawan, "Pengaruh Bahan Organik Terhadap Ketersediaan Fosfor Pada Tanah-Tanah Kaya Al dan Fe," Buletin Tanah dan Lahan, pp. 65-71, 2017.

[30] D. Prastya, I. Wahyudi and Baharudin, "Pengaruh Jenis dan Komposisi Pupuk Kandang dan Pupuk NPK Terhadap Serapan Nitrogen dan Hasil Bawang Merah (Allium ascalonium L.) Varietas Lembah Palu di Entisol Sidera," Journal Agrotekbis, pp. 4(4), 384-393, 2016.

[31] T. A. Muhammad, B. Zaman and Purwono, "Pengaruh Penambahan Pupuk Kotoran Kambing 
Terhadap Hasil Pengomposan Daun Kering di TPST UNDIP," Jurnal Teknik Lingkungan, pp. Vol 6 No.3, 1-12, 2017.

[32] F. Nuro, D. Priadi and E. S. Mulyaningsih, "Efek Pupuk Organik Terhadap Sifat Kimia Tanah dan Produksi Kangkung Darat (Ipomoea reptans Poir.)," in Prosiding Seminar Nasional Hasil-Hasil PPM IPB 2016, Bogor, 2016. 